\title{
On the Vertical Distribution of Vertical Velocity
}

\author{
By S. Kubota \\ Meteorological Research Institute, Tokyo, Japan \\ (Manuscript received 31 May 1957)
}

\begin{abstract}
In this faper the author investigated the vertical distribution of vertical velocity, by applying the double-Fourier series to the $\omega$-equation. And we can derive the conclusion that the parabolic distribution usually assumed in the parametric representation does hold generally in the large scale disturbances, but its validity is questionable for the small scale disturbances. It may be said that the level of the maximum vertical velocity locates at the $500 \mathrm{mb}$ level for the large scale and at the $700 \mathrm{mb}$ level for the small scale disturbances, and such displacement depends upon the stability of the atmosphere.
\end{abstract}

\section{Introduction}

In the numerical integration of the vorticity equation, the parabolic or sinusoidal distribution is sometimes assumed in order to take into account the baroclinic effect into the vorticity change. Someone is suspicious about this statistical and empirical assumption, however, the magnitude of errors resulted from this assumption is the second order for the large scale disturbances and it is not so important what kind of assumption should be taken, provided the general aspect be similar to the real atmosphere.

This simplification is convenient for the long range forecasting. Meanwhile, the vertical velocity has been estimated to be rather complicated in such small scale disturbances because it might induce the local heavy rain or control the motion of typhoons. Therefore, the parameter model is not suitable for the study of small scale disturbances from the practical point of view in calculation. The author studied these presumptions in the sections 2 and 3 .

2. Integratin of $\omega$-equation by the doubleFourier series

If we put

$$
\begin{aligned}
\omega & =\sum_{m} \sum_{n} \omega m n \\
& =\sum_{m} \sum_{n}\left(a_{m n} \cos m x \cos n y+b_{m n} \cos m x \sin n y\right.
\end{aligned}
$$

$$
\begin{aligned}
& \left.\quad+c_{m n} \sin m x \cos n y+d_{m n} \sin m x \sin n y\right) \\
& F=\sum_{m} \sum_{n} F_{m n} \\
& =\sum_{m} \sum_{n}\left(A_{m n} \cos m x \cos n y+B_{m n} \cos m x \sin n y\right. \\
& \left.\quad+C_{m n} \sin m x \cos n y+D_{m n} \sin m x \sin n y\right)
\end{aligned}
$$

the simplified $\omega$-equation

$$
\begin{aligned}
\kappa \nabla^{2} \omega+f^{2} \omega p p=F & \equiv g \frac{\partial}{\partial p} J(z, f+\varsigma) \\
& -\frac{g^{2}}{f} \nabla^{2} J\left(z, z_{p}\right)
\end{aligned}
$$

can be rewritten into the ensemble of such equations as

$$
-\left(m^{2}+n^{2}\right) \kappa \omega_{m n}+f^{2} \omega_{m n p}=F_{m n}
$$

where the suffix $p$ denotes the differentiation with respect to the pressure $p$, and

$$
\begin{aligned}
\kappa & \equiv-\alpha \frac{\partial \ln \theta}{\partial p}=-\alpha_{p}-\frac{C_{v}}{C_{p}} \frac{\alpha}{p} \\
& =g\left[z_{p p}+\frac{C_{v}}{C_{p}} \frac{1}{p} z_{p}\right]
\end{aligned}
$$

Then, in order to see the vertical distribu

100

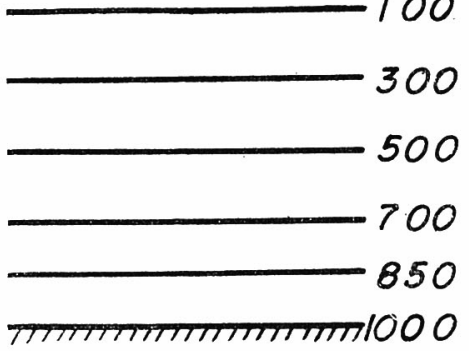

Fig. 1. tion 0 in wh be se (2) in where

$M_{m}$$$
\delta
$$

where coeffic tembe rakan 
tion of $\omega(p)$ corresponding to the values $F(p)$, in which $p=300,500,700$ and $850 \mathrm{mb}$ as can be seen in Fig. 1, we expressed the equation (2) in the form (3)

where

$$
\begin{aligned}
& M_{m n}= \\
& 0 \\
& 0 \\
& \text {, } \frac{8}{7} \delta^{2} \\
& \text {, } 0 \\
& \text { unit of } m, n=\frac{2 \times 3.14}{350 \times 10^{3} \times 11} m^{-1} \\
& =1.631 \times 10^{-6} \mathrm{~m}^{-1} \text {. }
\end{aligned}
$$$$
-\left(m^{2}+n^{2}\right) \kappa_{300}-2 \delta^{2}, \delta^{2} \quad, 0 \quad, 0
$$$$
\delta^{2} \quad,-\left(m^{2}+n^{2}\right) \kappa_{500}-2 \delta^{2}, \delta^{2}
$$$$
,-\left(m^{2}+n^{2}\right) \kappa_{700}-\frac{8}{3} \delta^{2}, \frac{32}{21} \delta^{2}
$$$$
\frac{16}{9} \delta^{2}
$$

where $\kappa_{300}, \kappa_{500}$, etc. denote the stability coefficients for the levels $300,500, \cdots \cdots \mathrm{mb}$, and

The normal values of $\kappa^{*}\left(\kappa \kappa^{*}=g\right)$ for September and December calculated by T. Murakami are used in this calculation (Table 1 ).

$$
\left.\begin{array}{l}
\boldsymbol{\omega}_{m n}(300) \\
\boldsymbol{\omega}_{m n}(500) \\
\boldsymbol{\omega}_{m n}(700)
\end{array}\right) \quad M_{m n}=\left(\begin{array}{l}
F_{m n}(300) \\
F_{m n}(500) \\
F_{m n}(700) \\
F_{m n}(850)
\end{array}\right.
$$

\begin{tabular}{|c|c|c|c|c|c|c|c|c|c|}
\hline$-M_{0}^{-1}=$ & $\begin{array}{l}0.778 \\
0.556 \\
0.333 \\
0.167\end{array}$ & $\begin{array}{l}0.556 \\
1.111 \\
0.667 \\
0.333\end{array}$ & $\begin{array}{l}0.292 \\
0.583 \\
0.875 \\
0.437\end{array}$ & $\begin{array}{l}0.125 \\
0.250 \\
0.375 \\
0.469\end{array}$ & & & & & \\
\hline$-M_{1}^{-1}=$ & $\begin{array}{l}0.548 \\
0.293 \\
0.143 \\
0.065\end{array}$ & $\begin{array}{l}0.293 \\
0.691 \\
0.338 \\
0.154\end{array}$ & $\begin{array}{l}0.125 \\
0.296 \\
0.573 \\
0.260\end{array}$ & $\left.\begin{array}{l}0.049 \\
0.115 \\
0.223 \\
0.357\end{array}\right)$ & $-M_{2}^{-1}=$ & $\begin{array}{l}0.439 \\
0.191 \\
0.080 \\
0.033\end{array}$ & $\begin{array}{l}0.191 \\
0.519 \\
0.216 \\
0.090\end{array}$ & $\begin{array}{l}0.070 \\
0.189 \\
0.443 \\
0.184\end{array}$ & $\begin{array}{l}0.024 \\
0.067 \\
0.158 \\
0.300\end{array}$ \\
\hline$-M_{4}^{-1}=$ & $\begin{array}{l}0.322 \\
0.104 \\
0.033 \\
0.012\end{array}$ & $\begin{array}{l}0.104 \\
0.356 \\
0.115 \\
0.041\end{array}$ & $\begin{array}{l}0.029 \\
0.100 \\
0.314 \\
0.112\end{array}$ & $\begin{array}{l}0.009 \\
0.031 \\
0.096 \\
0.235\end{array}$ & $-M_{5}^{-1}=$ & $\begin{array}{l}0.286 \\
0.082 \\
0.024 \\
0.008\end{array}$ & $\begin{array}{l}0.082 \\
0.310 \\
0.090 \\
0.030\end{array}$ & $\begin{array}{l}0.021 \\
0.079 \\
0.276 \\
0.092\end{array}$ & $\begin{array}{l}0.006 \\
0.022 \\
0.079 \\
0.214\end{array}$ \\
\hline$-M_{9}^{-1}=$ & $\begin{array}{l}0.200 \\
0.040 \\
0.008 \\
0.002\end{array}$ & $\begin{array}{l}0.040 \\
0.208 \\
0.043 \\
0.011\end{array}$ & $\begin{array}{l}0.007 \\
0.038 \\
0.191 \\
0.050\end{array}$ & $\left.\begin{array}{l}0.002 \\
0.009 \\
0.043 \\
0.159\end{array}\right)$ & $-M_{13} \cdot-1=$ & $\begin{array}{l}0.154 \\
0.024 \\
0.004 \\
0.001\end{array}$ & $\begin{array}{l}0.024 \\
0.158 \\
0.026 \\
0.005\end{array}$ & $\begin{array}{l}0.003 \\
0.023 \\
0.147 \\
0.031\end{array}$ & $\begin{array}{l}0.001 \\
0.004 \\
0.026 \\
0.123\end{array}$ \\
\hline$-\mathbf{M}_{1}^{-1}=$ & $\begin{array}{l}0.483 \\
0.231 \\
0.072 \\
0.034\end{array}$ & $\begin{array}{l}0.231 \\
0.590 \\
0.184 \\
0.087\end{array}$ & $\begin{array}{l}0.063 \\
0.161 \\
0.324 \\
0.153\end{array}$ & $\left.\begin{array}{l}0.026 \\
0.065 \\
0.131 \\
0.204\end{array}\right)$ & $-\mathbf{M}_{2}^{-1}=$ & $\begin{array}{l}0.374 \\
0.159 \\
0.072 \\
0.032\end{array}$ & $\begin{array}{l}0.159 \\
0.494 \\
0.224 \\
0.100\end{array}$ & $\begin{array}{l}0.063 \\
0.196 \\
0.486 \\
0.217\end{array}$ & $\begin{array}{l}0.024 \\
0.075 \\
0.186 \\
0.335\end{array}$ \\
\hline $\mathbf{M}_{4}^{-1}=$ & $\begin{array}{l}0.257 \\
0.079 \\
0.029 \\
0.012\end{array}$ & $\begin{array}{l}0.079 \\
0.333 \\
0.122 \\
0.049\end{array}$ & $\begin{array}{l}0.025 \\
0.107 \\
0.360 \\
0.146\end{array}$ & $\left.\begin{array}{l}0.009 \\
0.037 \\
0.125 \\
0.278\end{array}\right)$ & $-\mathbf{M}_{5}^{-1}=$ & $\begin{array}{l}0.224 \\
0.061 \\
0.020 \\
0.008\end{array}$ & $\begin{array}{l}0.061 \\
0.289 \\
0.097 \\
0.037\end{array}$ & $\begin{array}{l}0.018 \\
0.085 \\
0.321 \\
0.124\end{array}$ & $\begin{array}{l}0.006 \\
0.028 \\
0.106 \\
0.259\end{array}$ \\
\hline
\end{tabular}

$x \sin n y$

$x \sin n y$

(1) of such

(2) ntiation

distribl:

Table 2 
$75_{\text {th }}$ Anniversary Volume of the Journal of the Meteorogical Society of Japan

$-\mathbf{M}_{9}{ }^{-1}=\left(\begin{array}{llll}0.148 & 0.028 & 0.006 & 0.002 \\ 0.028 & 0.192 & 0.042 & 0.012 \\ 0.007 & 0.048 & 0.227 & 0.064 \\ 0.002 & 0.016 & 0.074 & 0.205\end{array}\right) \quad-\mathbf{M}_{13}{ }^{-1}=\left(\begin{array}{llll}0.111 & 0.016 & 0.003 & 0.001 \\ 0.016 & 0.145 & 0.025 & 0.006 \\ 0.003 & 0.029 & 0.180 & 0.044 \\ 0.001 & 0.008 & 0.051 & 0.172\end{array}\right)$

=const. and $\boldsymbol{M}_{5}^{-1}$ for $m^{2}+n^{2}=5$ and $\kappa(p)$ as shown in Table 1 and so on. The atmosphere in the latter case is more stable than the former. These matrices show that if the unit external force $F_{m n}$ should be given at $500 \mathrm{mb}$ level in the atmosphere of $m^{2}+n^{2}=4$ and $\kappa=3.35$, then $\omega_{4}(300)=0.104, \omega_{4}(500)=0.356$, $\omega_{4}(700)=0.115$ and $\omega_{4}(850)=0.041$ are derived, and so on.

It can be seen from these matrices that if the external forces $F_{m n}$ 's are distributed homogeneously in the vertical, the maximum $\omega_{m}$ n is situated in the upper level for the large scale disturbances and forced down towards the lower level as the disturbances become smaller and at last the influence of external

forces does not reach so far in the vertical direction so that the distribution of vertical velocity becomes similar to that of external forces.

To see the aspects of $\omega$, strictly speaking, the observed values of external forces $F_{m n}$ must be given. Here, however, in order to see the rough feature of the distribution of $\omega_{m n}$, the author introduced

$$
z=H+\bar{z}+A(p)\left[h-h_{n}\right]
$$

into

$$
F \equiv \sum \sum F_{m n}=g \frac{\partial}{\partial p} J(z, f+\zeta)-\frac{g^{2}}{f} \nabla^{2} J\left(z, z_{p}\right)
$$

As to the notations and the value of $A(p)$ used in these expressions the paper by Eliassen (1952) should be referred to.

\begin{tabular}{|c|c|c|c|c|c|c|c|c|c|c|}
\hline & 10 & 9 & 8 & 7 & 6 & 5 & 4 & 3 & 2 & $1 \times 100 \mathrm{mb}$ \\
\hline$A(p)$ & -0.8 & -0.7 & -0.6 & -0.5 & -0.2 & 0.3 & 1.1 & 1.7 & 1.0 & -0.2 \\
\hline$A^{\prime}(p)$ & & 1 & -0.65 & 0.2 & & 0.65 & & -0.05 & & \\
\hline$A A^{\prime}(p)$ & & & -0.65 & -1.0 & & 1.95 & & 0.85 & & \\
\hline
\end{tabular}

Table 3

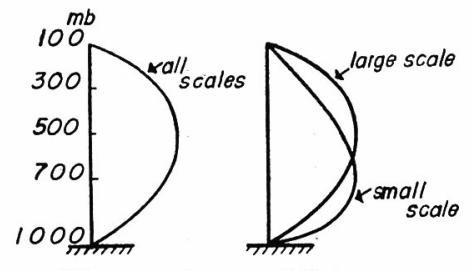

$\kappa(p)=$ const.

$F(p)=$ const. $\kappa(p) \neq$ const.

$F(p)=$ const.

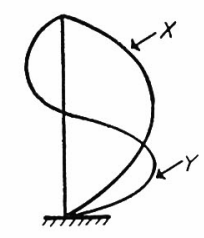

$\kappa(p)=$ const. large seale

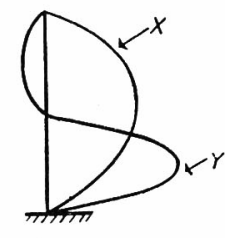

$\kappa(p)=$ const. small scale

Fig. 2

Fig. 2 show some examples for $F=X+Y$ and

$$
X \propto A^{\prime} J\left(h, \nabla^{2} \bar{z}\right) \quad Y \propto A A^{\prime} J\left(h, \nabla^{2} h\right)
$$

It can be suggested from these figures that the vertical distribution of $\omega$ corresponding to the term $X$ is nearly parabolic and the $500 \mathrm{mb}$ level is non-divergent, meanwhile the distribution corresponding to the term $Y$ becomes less parabolic, the non-divergent level becoming lower until $700 \mathrm{mb}$ level, and the $500 \mathrm{mb}$ level becomes the level of the greatest divergence. The rate of deformation of this kind becomes greater, in proportion to the scale of disturbance and stability of the atmosphere. But in the actual atmosphere the composite effect of these terms appears and the distribution due to the term I disappears in the large scale disturbances, because their variation in the vertical is not so large.
3. $\mathrm{T}$

In autho level series

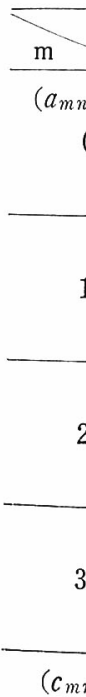

$\left(c_{m}\right.$ 
3. The distribution of $\omega_{n n}$ calculated by use of grid points

In order to check these conclusions, the author expanded the value of $\omega$ at each level into the twelve term double-Fourier series as shown in the Table 4 . The values of $\omega$ used in this case are those calculated by Mr. T. Murakami by use of grid points for the map. Now, Table 4 shows the complicated distribution. However, it can be said that our conclusions are also proved in this case.

Table $4 \quad(\mathrm{mb} / 12 \mathrm{hrs})$

\begin{tabular}{|c|c|c|c|c|c|c|c|c|}
\hline $\mathrm{m} n$ & 0 & 1 & 2 & 3 & 0 & 1 & 2 & 3 \\
\hline $\begin{array}{r}\left(a_{m n}\right) \\
0\end{array}$ & $\begin{array}{l}1.08 \\
1.90 \\
1.11 \\
0.51\end{array}$ & $\begin{array}{l}-0.12 \\
-0.51 \\
-0.32 \\
-0.29\end{array}$ & $\begin{array}{r}0.12 \\
0.02 \\
-0.11 \\
0.02\end{array}$ & $\begin{array}{r}-0.19 \\
-0.07 \\
0.05 \\
0.09\end{array}$ & $\left(b_{m n}\right)$ & & & \\
\hline 1 & $\begin{array}{l}0.47 \\
1.23 \\
0.95 \\
0.44\end{array}$ & $\begin{array}{r}0.14 \\
-0.27 \\
-0.41 \\
-0.59\end{array}$ & $\begin{array}{l}0.89 \\
1.18 \\
0.83 \\
0.36\end{array}$ & $\begin{array}{l}-0.14 \\
-0.62 \\
-1.02 \\
-0.75\end{array}$ & $\begin{array}{l}-0.98 \\
-2.00 \\
-1.06 \\
-0.39\end{array}$ & $\begin{array}{r}-0.84 \\
-0.55 \\
-0.07 \\
0.24\end{array}$ & $\begin{array}{l}0.54 \\
1.19 \\
0.74 \\
0.45\end{array}$ & $\begin{array}{l}-0.38 \\
-0.55 \\
-0.38 \\
-0.04\end{array}$ \\
\hline 2 & $\begin{array}{l}-1.58 \\
-2.62 \\
-1.73 \\
-0.93\end{array}$ & $\begin{array}{l}1.27 \\
2.28 \\
1.87 \\
0.94\end{array}$ & $\begin{array}{l}-0.29 \\
-0.62 \\
-0.88 \\
-0.44\end{array}$ & $\begin{array}{l}0.16 \\
0.55 \\
0.36 \\
0.35\end{array}$ & $\begin{array}{l}0.73 \\
1.14 \\
0.62 \\
0.05\end{array}$ & $\begin{array}{r}-0.08 \\
0.86 \\
1.64 \\
1.67\end{array}$ & $\begin{array}{l}-0.46 \\
-0.95 \\
-1.08 \\
-0.92\end{array}$ & $\begin{array}{r}0.25 \\
0.42 \\
0.05 \\
-0.35\end{array}$ \\
\hline 3 & $\begin{array}{l}-0.38 \\
-0.60 \\
-0.55 \\
-0.47\end{array}$ & $\begin{array}{r}0.06 \\
-0.09 \\
-0.16 \\
0.07\end{array}$ & $\begin{array}{r}-0.11 \\
-0.06 \\
0.25 \\
0.29\end{array}$ & $\begin{array}{l}-0.24 \\
-0.34 \\
-0.36 \\
-0.52\end{array}$ & $\begin{array}{l}0.30 \\
0.61 \\
0.45 \\
0.16\end{array}$ & $\begin{array}{r}-0.12 \\
-0.11 \\
-0.24 \\
0.04\end{array}$ & $\begin{array}{l}-0.18 \\
-0.32 \\
-0.27 \\
-0.36\end{array}$ & $\begin{array}{l}0.32 \\
0.24 \\
0.36 \\
0.36\end{array}$ \\
\hline$\left(c_{m n}\right)$ & & $\begin{array}{l}1.46 \\
1.78 \\
1.16 \\
0.67\end{array}$ & $\begin{array}{r}0.64 \\
0.05 \\
-0.13 \\
-0.25\end{array}$ & $\begin{array}{r}-0.03 \\
0.14 \\
0.11 \\
0.09\end{array}$ & $\left(d_{m n}\right)$ & & & \\
\hline 1 & & $\begin{array}{l}-0.85 \\
-0.88 \\
-0.09 \\
-0.27\end{array}$ & $\begin{array}{l}0.55 \\
1.00 \\
0.65 \\
0.11\end{array}$ & $\begin{array}{l}0.27 \\
0.34 \\
0.39 \\
0.48\end{array}$ & & $\begin{array}{l}-1.51 \\
-2.70 \\
-1.44 \\
-0.74\end{array}$ & $\begin{array}{r}-0.31 \\
0.12 \\
0.87 \\
0.85\end{array}$ & $\begin{array}{l}-0.34 \\
-0.16 \\
-0.41 \\
-0.55\end{array}$ \\
\hline 2 & & $\begin{array}{l}-0.62 \\
-0.88 \\
-0.35 \\
-0.23\end{array}$ & $\begin{array}{l}-0.36 \\
-0.61 \\
-0.03 \\
-0.08\end{array}$ & $\begin{array}{r}0.12 \\
0.10 \\
-0.15 \\
-0.17\end{array}$ & & $\begin{array}{l}0.67 \\
1.60 \\
1.28 \\
0.51\end{array}$ & $\begin{array}{r}-0.08 \\
0.27 \\
0.77 \\
0.68\end{array}$ & $\begin{array}{l}-0.16 \\
-0.37 \\
-0.27 \\
-0.44\end{array}$ \\
\hline 3 & & $\begin{array}{l}-0.05 \\
-0.44 \\
-0.77 \\
-0.75\end{array}$ & $\begin{array}{r}0.02 \\
0.08 \\
0.06 \\
-0.06\end{array}$ & $\begin{array}{l}-0.47 \\
-0.35 \\
-0.25 \\
-0.09\end{array}$ & & $\begin{array}{l}0.28 \\
0.76 \\
0.38 \\
0.11\end{array}$ & $\begin{array}{r}0.31 \\
-0.11 \\
0.22 \\
-0.12\end{array}$ & $\begin{array}{r}0.07 \\
-0.03 \\
-0.07 \\
-0.26\end{array}$ \\
\hline
\end{tabular}

\section{References}

1) Eliassen, A., 1952: Simplified Dynamic Models of the Atmosphere, Designed for the Purpose of Numerical Weather Prediction. Tellus, 4, 145. -2) Murakami, T., Y. Masuda and A. Arakawa, 1956: On the Distribution of Vertical Velocity and the Numerical Prediction of the Movement of Typhoon. Pap. Meteor. Geophys. 7, 211-250. -3) Murakami, T. 1957: Mean Vertical Velocity and Heat Sources over the Far East during the Rainy Season (to be published). 